\title{
Can the U.S. Avoid Urban Combat in Baghdad?
}

\author{
A Monograph \\ by \\ MAJ Robert F. Whittle, Jr. \\ U.S. Army
}

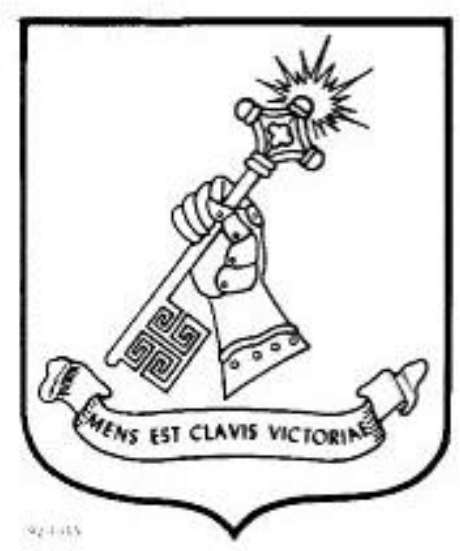

School of Advanced Military Studies

United States Army Command and General Staff College

Fort Leavenworth, Kansas

AY 02-03 


\section{Report Documentation Page}

Public reporting burden for the collection of information is estimated to average 1 hour per response, including the time for reviewing instructions, searching existing data sources, gathering and maintaining the data needed, and completing and reviewing the collection of information. Send comments regarding this burden estimate or any other aspect of this collection of information, including suggestions for reducing this burden, to Washington Headquarters Services, Directorate for Information Operations and Reports, 1215 Jefferson Davis Highway, Suite 1204, Arlington VA 22202-4302. Respondents should be aware that notwithstanding any other provision of law, no person shall be subject to a penalty for failing to comply with a collection of information if it does not display a currently valid OMB control number.

\begin{tabular}{|c|c|c|}
\hline $\begin{array}{l}\text { 1. REPORT DATE } \\
\mathbf{2 2} \text { MAY } \mathbf{2 0 0 3}\end{array}$ & 2. REPORT TYPE & $\begin{array}{l}\text { 3. DATES COVERED } \\
\text { - }\end{array}$ \\
\hline \multirow{3}{*}{\multicolumn{2}{|c|}{$\begin{array}{l}\text { Can the U.S. avoid urban combat in Baghdad? } \\
\text { Canle }\end{array}$}} & 5a. CONTRACT NUMBER \\
\hline & & 5b. GRANT NUMBER \\
\hline & & 5c. PROGRAM ELEMENT NUMBER \\
\hline \multirow{3}{*}{\multicolumn{2}{|c|}{$\begin{array}{l}\text { 6. AUTHOR(S) } \\
\text { Robert Whittle, Jr.; }\end{array}$}} & 5d. PROJECT NUMBER \\
\hline & & 5e. TASK NUMBER \\
\hline & & 5f. WORK UNIT NUMBER \\
\hline \multicolumn{2}{|c|}{$\begin{array}{l}\text { 7. PERFORMING ORGANIZATION NAME(S) AND ADDRESS(ES) } \\
\text { US Army School of Advanced Military Studies, } 250 \text { Gibbon Ave,Fort } \\
\text { Leavenworth,KS,66027, }\end{array}$} & $\begin{array}{l}\text { 8. PERFORMING ORGANIZATION } \\
\text { REPORT NUMBER } \\
\text { ATZL-SWV }\end{array}$ \\
\hline \multirow{2}{*}{\multicolumn{2}{|c|}{ 9. SPONSORING/MONITORING AGENCY NAME(S) AND ADDRESS(ES) }} & 10. SPONSOR/MONITOR'S ACRONYM(S) \\
\hline & & $\begin{array}{l}\text { 11. SPONSOR/MONITOR'S REPORT } \\
\text { NUMBER(S) }\end{array}$ \\
\hline
\end{tabular}

12. DISTRIBUTION/AVAILABILITY STATEMENT

Approved for public release; distribution unlimited

13. SUPPLEMENTARY NOTES

14. ABSTRACT

Some military thinkers believe that it is possible to avoid urban combat when attacking and seizing a city. They claim that U.S. forces can do this by taking an Indirect Approach. The proposal is basically a siege of the city. This course of action is appealing to the media, the public, and politicians who wish to avoid U.S. casualties. The proposal makes sense when described using a hypothetical situation. Will the proposal's logic hold when applied to a realistic scenario? One way to evaluate the proposal is to choose a scenario and then do a course of action assessment. By using the situation in Iraq in mid-March, 2003, it was possible to develop a military estimate that described the conditions in Baghdad. Using MG(R) Robert H. Scales' description of the Indirect Approach, the campaign that places U.S. or allied forces near Baghdad was designed. MB Scales' proposal was then used to develop a course of action that attacks the city indirectly. The feasibility of the course of action was then evaluated by comparing its results to the end state that the U.S. desired in Iraq. The Indirect Approach does not contribute towards the U.S.'s desired end state and objectives. One problem is that the Iraqi regime may be able to withstand the siege over time, in which case a stalemate will occur. In addition, without using forces on the ground and human intelligence inside the city, U.S. forces may not be able to find and eliminate WMD early enough in the operation. Finally, the extraordinary physical and psychological effects of the siege will not be compatible to U.S. goals of liberating the Iraqi people and installing a regime that does not pose a threat to the U.S. Instead, the siege will brew hatred among the Iraqi people and the rest of the Arab world.

15. SUBJECT TERMS

16. SECURITY CLASSIFICATION OF:

a. REPORT unclassified

\section{b. ABSTRACT} unclassified c. THIS PAGE unclassified
17. LIMITATION OF ABSTRACT 1
18. NUMBER OF PAGES 39 19a. NAME OF RESPONSIBLE PERSON 
Standard Form 298 (Rev. 8-98) Prescribed by ANSI Std Z39-18 


\section{SCHOOL OF ADVANCED MILITARY STUDIES MONOGRAPH APPROVAL}

MAJ Robert F. Whittle, J r.

Title of Monograph: Can the U.S. Avoid Urban Combat in Baghdad?

Approved by:

Dr. William J. Gregor

Monograph Director

Professor and Director Academic Affairs,

Robert H. Berlin, Ph.D. School of Advanced Military Studies

Director, Graduate Degree

Philip J. Brookes, Ph.D. Program 


\section{Abstract}

CAN THE U.S. AVOID URBAN COMBAT IN BAGHDAD? by MAJ Robert F. Whittle, Jr., U.S. Army, 39 pages.

Some military thinkers believe that it is possible to avoid urban combat when attacking and seizing a city. They claim that U.S. forces can do this by taking an Indirect Approach. The proposal is basically a siege of the city. This course of action is appealing to the media, the public, and politicians who wish to avoid U.S. casualties. The proposal makes sense when described using a hypothetical situation. Will the proposal's logic hold when applied to a realistic scenario? One way to evaluate the proposal is to choose a scenario and then do a course of action assessment.

By using the situation in Iraq in mid-March, 2003, it was possible to develop a military estimate that described the conditions in Baghdad. Using MG(R) Robert H. Scales' description of the Indirect Approach, the campaign that places U.S. or allied forces near Baghdad was designed. MG Scales' proposal was then used to develop a course of action that attacks the city indirectly. The feasibility of the course of action was then evaluated by comparing its results to the end state that the U.S. desired in Iraq.

The Indirect Approach does not contribute towards the U.S.'s desired end state and objectives. One problem is that the Iraqi regime may be able to withstand the siege over time, in which case a stalemate will occur. In addition, without using forces on the ground and human intelligence inside the city, U.S. forces may not be able to find and eliminate WMD early enough in the operation. Finally, the extraordinary physical and psychological effects of the siege will not be compatible to U.S. goals of liberating the Iraqi people and installing a regime that does not pose a threat to the U.S. Instead, the siege will brew hatred among the Iraqi people and the rest of the Arab world. 


\section{TABLE OF CONTENTS}

CHAPTER ONE: INTRODUCTION 


\section{CHAPTER ONE: INTRODUCTION}

Some professional soldiers and military experts believe that technology can enable armed forces to avoid direct combat. These enthusiasts think that sophisticated precision weaponry will enable forces to control warfare from a distance. A few military thinkers extend this belief to urban operations. As the U.S. prepares for a possible war with Iraq, the media has given voice to those who feel that U.S. technological advantages will avoid casualties in cities. One adherent to the school of thought that U.S. forces may be able to avoid the difficulties of urban combat in Baghdad is COL(R) David Hackworth. He said in a media interview, "all we have to do is encircle the cities that he has dug in on and shut off the electricity, shut off the lights and then hit him with non-lethal weapons . . . and the end result will be we'll win without having a lot of bloodshed." Hackworth's comments outline an attractive course of action, one that parallels the Indirect Approach that $\mathrm{MG}(\mathrm{R})$ Robert H. Scales, Jr., suggests. $\mathrm{MG}(\mathrm{R})$ Scales believes that the U.S. could use an approach similar to Hackworth's to defeat military forces in enemy cities.

Scales described his method in an article titled "The Indirect Approach: How US Military Forces Can Avoid the Pitfalls of Future Urban Warfare," published in the October 1998 issue of the Armed Forces Journal International. ${ }^{2}$ The article in essence argues that it is possible to achieve success in urban operations without sending ground troops into the city. The course of action is initially very appealing to the public, civilian leadership, and military planners intent on avoiding losing large numbers of troops in urban combat. While the Indirect Approach works soundly when applied to a hypothetical situation, it is not clear that the U.S. can apply the approach in the real world. To assess the Indirect Approach realistically it is necessary to choose a scenario and then do a course of action assessment; that is, develop a military estimate.

\footnotetext{
${ }^{1}$ David Hackworth, "Interview with Colonel David Hackworth," (Fox \& Friends Fox News Channel, 27 August 2002).

${ }^{2}$ Robert H. Scales, Jr., "The Indirect Approach: How U.S. Military Forces Can Avoid the Pitfalls of Future Urban Warfare," Armed Forces Journal International, October 1998, 68-73.
} 
Choosing a scenario was quite easy since the United States has been threatening and planning war with Iraq for almost a year. This military assessment incorporates the situation and conditions in Iraq during mid-March, 2003. The military assessment required a comparison between military planning course of action development procedures and the description of the Indirect Approach developed by $\mathrm{MG}(\mathrm{R})$ Scales. The comparison took into account both $\mathrm{MG}(\mathrm{R})$ Scales' proposal and the campaign that places U.S. or allied forces near Baghdad.

MG(R) Scales' proposal has three parts: isolate the city while seizing control of the infrastructure and public services, take advantage of time, which would now be on the side of U.S. forces, and wait for the city to implode. ${ }^{3}$ The proposal is sufficiently detailed that a military estimate of the requirements is possible. Similarly, military intelligence estimates are available to support analysis of the effects of the investment and its effects on the population. However, before Baghdad can be isolated, it is necessary to get from the border to Baghdad. Hence, a campaign needs to be designed.

Assessing the campaign before an investment of Baghdad required an analysis of the likely enemy courses of action in response to a variety of U.S. courses of action. The intent was to identify what effect different courses of action would have on an investment. The campaign design was informed by $\mathrm{MG}(\mathrm{R})$ Scales' other writings to the extent possible. That was necessary to avoid creating impossible conditions for his concept. Despite the care taken to remain faithful to $\mathrm{MG}(\mathrm{R})$ Scales, it was also necessary to apply military judgement to fill in the campaign elements needed to meet the requirements of joint doctrine. The items MG(R) Scales did not address were then analyzed to determine both their relevance and importance.

After the course of action was developed and assessed it was clear that the Indirect Approach is not a feasible course of action for a U.S. attack on Baghdad. Although the U.S. can invest Baghdad, a long siege does not work to the benefit of either U.S. military forces or U.S.

\footnotetext{
${ }^{3}$ Ibid., 73 .
} 
policy. U.S. forces cannot depend on the Iraqi people to overthrow their own government. A siege will foster unnecessary ill will among the Iraqi and Arab people, thereby making it difficult for the U.S. to win the peace. A humanitarian crisis will divert resources and focus international pressure on ending the siege. Finally, the course of action will allow Iraqi political and military forces to find sanctuary from U.S. forces.

However, a feasible course of action for regime change in Baghdad that incorporates some of MG Scales' ideas is possible. That course of action makes use of close combat when necessary to strike or control key targets in the city. It avoids unnecessary damage to the infrastructure and unnecessary suffering among the Iraqi civilians. Most importantly, it minimizes the time that it takes to gain control of Baghdad and Iraq.

\section{CHAPTER TWO: THE INDIRECT APPROACH}

Urban operations are very difficult. The characteristics of a city have a large effect on military operations. Due to those effects, military forces that have a large advantage in open terrain may lose those advantages in urban terrain. The difficulties presented to an attacker can make an urban battle protracted and deadly. A method of describing the characteristics of cities is to use the urban triad: physical terrain, population, and infrastructure. ${ }^{4}$

The physical terrain of a city is extremely complex. The ground usually has topographical features such as hills, depressions, spurs, saddles, and draws. A city usually contains significant water barriers. Many cities lie along rivers because the rivers provide power, water, and transportation. The ocean also blocks at least one side of any seaport. A city has manmade structures that are both above and below the ground. Many of the structures are more than one story tall and connect together. There are underground tunnels such as sewers and subway systems, as well as above ground throughways such as highways and roads. The sheer number of 
structures and the complexity of the city's layout effectively fold a large battlefield into a very small space. Consequently, military units encounter a great number of obstacles. These characteristics have several effects on military operations.

The terrain provides an abundance of cover and concealment that hinders reconnaissance and surveillance. Subway tunnels and sewers provide concealed avenues of approach. Structures block or shorten a soldier's line-of-sight. When the line-of-sight is blocked, it is not possible to use weapons at the maximum effective range. In cities, soldiers are often surprised when they turn a corner or enter a new structure. Urban terrain frequently negates the standoff advantage that many U.S. weapons systems enjoy in open terrain. Communications can be much more difficult in the complex terrain. Urban structures can block cellular telephone, satellite, and radio systems. The poor communication makes centralized control more difficult. While there are some measures an attacker can take to maintain communications, mobile units can lose contact with their headquarters. Consequently, urban terrain frequently forces military units to decentralize operations.

By definition, a relatively large population inhabits a city. Most of the inhabitants are civilians and noncombatants. Therefore, military units must contend with many civilians. In the presence of noncombatants, cultural artifacts, embassies, and hospitals, it is hard for military forces to avoid creating collateral damage. Avoiding collateral damage is even more difficult when enemy forces choose to masquerade as civilians or operate out of hospitals and religious sites. To avoid creating civilian casualties, military forces may restrict fires to direct fire and precision weapons to ensure positive identification and control. Therefore, military forces may not be able to capitalize on their indirect fire capabilities.

The infrastructure of a city is a system of systems that includes highways, mass transit, water and wastewater treatment, garbage disposal, power, police, and medical services. Ideally,

\footnotetext{
${ }^{4}$ Joint Chiefs of Staff. Joint Publication 3-06, Doctrine for Joint Urban Operations (Washington, D.C.: Joint Chiefs of Staff, 2002), vii.
} 
the infrastructure of a city enables the population to move around the city with relative ease and to live under relatively good health conditions. However, if some of the systems are missing or in poor repair, a city can quickly become an unhealthy environment. The infrastructure is, in effect, the life support system of a city.

Military operations will affect the city's infrastructure, and as a result, further affect the population. For example, long power outages can cause permanent damage to water and wastewater treatment systems. Without access to clean water, disease can quickly break out among a city's population. "In order to operate successfully . . . a force must remove the cancer without killing the patient." ${ }^{5}$ In urban operations, military forces must plan and execute very carefully if they wish to avoid hurting the civilian population with the first and second order effects of the operations.

The characteristics of a city combine to affect military operations even further. Because the city provides a dramatic background consisting of noncombatants, damaged structures, and human suffering, the media will focus in on urban operations. Media attention brings international attention, and the resulting world focus can give actions at the tactical level strategic significance. Not only does an urban setting intensify media coverage of combat operations, it also increases the difficulty of the operations themselves.

When U.S. forces conduct operations inside of a city, the force loses many of the conventional advantages that it possesses in open terrain, and friendly casualties may increase. Dismounted U.S. infantry clearing a city block are just as vulnerable as their opponents are. Casualty rates from block-to-block fighting are likely to be high for friendly forces, enemy forces, and noncombatants. "Historical experience suggests that a rifle company (100-200 individuals)

\footnotetext{
${ }^{5}$ Duane Schattle, "Joint MOUT Mission Area Analysis and Mission Need Assessment," in The City's Many Faces, ed. Russell W. Glenn (Santa Monica, CA: RAND, 2000), 284.
} 
can take a defended city block in about 12 hours, with $30-45$ percent casualties." ${ }^{6}$ The U.S. military has not experienced such casualty rates since the Vietnam War.

Urban operations are also manpower intensive. ${ }^{7}$ Support requirements are extremely high, particularly if the city's infrastructure is largely disabled. Resupply and medical evacuation are needs that become more difficult in the maze of urban terrain. Strategic consumption quickly affects military forces as units drop off troops to secure terrain. The tremendous costs of urban operations compel civilian leaders and military planners to seek more economical ways to conduct combat operations in cities. One such method is the Indirect Approach.

MG(R) Robert H. Scales’ paper, “The Indirect Approach: How US Military Forces Can Avoid the Pitfalls of Future Urban Warfare, ${ }^{8,}$ is a proposal that challenges military thinkers to consider the way they do business. Scales, a former commandant of the U.S. Army's War College, is a creditable military thinker. In fact, FM 3-06, Urban Operations, lists Scales' book, Future Warfare, in the bibliography. ${ }^{9}$

MG(R) Robert H. Scales' developed his proposal in response to events in the Army's 1997 Winter Wargame. In July 1997, Scales presented his approach in a brief he gave at the Pentagon. ${ }^{10}$ The Wargame was set in the year 2020. Enemy forces were operating in an urban area, and U.S. forces sought to dislodge them. The objective was to get the population of the city to revolt against the enemy leadership, rather than use U.S. forces do it. Scales' group formed a

\footnotetext{
${ }^{6}$ Barry R. Posen, "Urban Operations: Tactical Realities and Strategic Ambiguities," in Soldiers in Cities: Military operation on Urban Terrain, ed. Michael C. Desch (Carlisle, PA: Strategic Studies Institute, 2001), 153-154.

${ }^{7}$ Mark Sumner, "The case for MOUT Doctrine," available from http://www.urbanoperations.com/jointdoctrine.htm; Internet; accessed 15 January 2003.

${ }^{8}$ Robert H. Scales, Jr., "The Indirect Approach: How U.S. Military Forces Can Avoid the Pitfalls of Future Urban Warfare," Armed Forces Journal International, October 1998, 68-73.

${ }^{9}$ Joint Chiefs of Staff. Joint Publication 3-06, Doctrine for Joint Urban Operations (Washington, D.C.: Joint Chiefs of Staff, 2002), E-8.

${ }^{10}$ Robert H. Scales, Jr., "Transcript of a Brief on the Army After Next," U.S. Army News Release 97a77, 10 July 1997.
} 
loose cordon around the city and tried to use precision strikes to cause the city to collapse. Scales said that it takes "time, but remember if the enemy retrenches into a city, he cedes maneuver, and therefore time then moves to your side." 11 Time is a key element of the Indirect Approach, and Scales made that clear in the next paper that he published on the concept.

Scales addressed time in the October 1998 issue of the Armed Forces Journal International. ${ }^{12}$ In this instance, Scales cited the spring 1998 Army 2025 Wargame as the basis for his observations. In that wargame, U.S. forces fought through urban areas. The casualties were excessively high and the fighting drawn out. Scales proposed an Indirect Approach to lower those costs. Although the article references the 2025 Wargame, the article is largely set in the present, and the approach utilizes current U.S. capabilities.

After writing his paper, Scales addressed the Indirect Approach again at a RAND conference. ${ }^{13}$ During the conference question and answer period, he elaborated further on his ideas. Scales stated the population is the center of gravity of a city. Scales spoke of establishing safe havens in suburban areas for the city's population. Scales comments in the speech and in the question/answer session that followed indicated that U.S. forces should be able to execute the Indirect Approach today.

Finally, MG Scales outlined how U.S. forces could use the Indirect Approach in Baghdad. In this excerpt from an article for Time, Mark Thompson quoted and paraphrased MG Scales' concept:

Robert Scales, a retired major general who used to run the U.S. Army War College, says the Americans should avoid door-to-door battles and instead cordon off the capital with a loose chain of tanks and armored vehicles. This

\footnotetext{
11 Ibid., 9.
}

${ }^{12}$ Robert H. Scales, Jr., "The Indirect Approach: How U.S. Military Forces Can Avoid the Pitfalls of Future Urban Warfare," Armed Forces Journal International, October 1998, 68-73.

${ }^{13}$ Robert H. Scales, Jr., "A MOUT Doctrinal Concept," in The City's Many Faces, Proceedings of the RAND Arroyo-MCWL-J8 UWG Urban Operations Conference, ed. Russell W. Glenn (Santa Monica, CA: RAND, 2000), 157-170. 
porous ring would allow civilians to flee the city center, where Saddam's soldiers--and perhaps the Iraqi leader himself--would be holed up, anxiously waiting for a "mother of all battles" that would never materialize. "You can be patient, with a minimum loss of life," says Scales, "or you can rush in and kill a lot of people on both sides."

Baghdad would seem particularly vulnerable to such a wait-it-out strategy. It is not even close to being self-sufficient. If U.S. troops cut off the supply of water, food, electricity and communications, civilians would no doubt quickly begin fleeing to the safety of refugee camps set up outside the cordon. The U.S. military could wait for the white flag of surrender to flutter outside the range of most of Saddam's weapons. Armed with intelligence gleaned from fleeing refugees, the Americans could attack key targets inside the city with long-range weapons. Such a siege could help nurture one prized U.S. goal: Saddam's falling at the hands of his own people. "Baghdad is one of those classic cities that happen to contain all the kindling necessary to spark a revolt," says Scales. "You'd have the ruling elite and the army cheek by jowl with the people, who despise both the elite and the army." ${ }^{14}$

Scales' comments to Time reveal that he believed the Indirect Approach could work in Baghdad.

He made it clear that he believed the U.S. currently has the capabilities to apply the Indirect Approach.

MG(R) Scales' proposal has “three fundamental concepts: using an Indirect Approach, using time to our advantage, and letting the city collapse on itself." ${ }^{15}$ Instead of approaching enemy forces in the city directly, Scales argues that forces should take an Indirect Approach.

The Indirect Approach to reducing cities requires the complete isolation of the city and the control of infrastructure and public services. U.S. forces control every avenue of approach. They also "control sources of food, power, water, and sanitation services." 16 Additionally, U.S. forces seize control of all internal communications and stifle "commercial, financial and governmental nodes." ${ }^{17}$ U.S. forces, therefore, provide the only information available to the residents. U.S. forces will hit only key pieces of terrain. Unmanned aerial vehicles provide

${ }^{14}$ Mark Thompson, "Going Door to Door," Time, 16 September 2002, 41.

${ }^{15}$ Robert H. Scales, Jr., "The Indirect Approach: How U.S. Military Forces Can Avoid the Pitfalls of Future Urban Warfare," Armed Forces Journal International, October 1998, 73.

${ }^{16}$ Ibid., 73.

${ }^{17}$ Ibid., 73. 
reconnaissance. U.S. forces avoid close combat and instead hit targets from a large distance, staying safely out of range of the enemy. ${ }^{18}$

The second concept in Scales' proposal is taking advantage of time. Using information operations, U.S. forces seek to convince the city's population that the enemy army is a "hostile occupying force." ${ }^{19}$ A key element of the strategy is that time is on the side of U.S. forces. In order to avoid a greater amount of bloodshed, U.S. forces patiently wait for the Indirect Approach to work. In time, the population turns against the enemy forces.

The third concept is the city's collapse. U.S. forces will encourage other organizations to establish sanctuaries and refugee camps for the citizens who flee the city. Coalition forces encourage the population to pass through the cordon to the camps. People who do not depart the city become rapidly displeased with the government.

In short, urban operations are extremely complicated and challenging. Any approach which avoids direct combat in urban operations is extremely appealing. MG Scales' Indirect Approach seeks to take a city while avoiding urban combat. This monograph shows the results from the application of a military estimate of how the method would work in Baghdad. The results are laid out in the order that they would occur during a campaign.

\section{CHAPTER THREE: THE CAMPAIGN}

\section{End State}

Defining the end state of a campaign is an essential element of campaign design. The United States' objectives in Iraq are well defined. Both the Congress and the President have agreed that any military action against Iraq must produce a regime change. The military operations must also locate and destroy any nuclear, chemical, or biological weapons and the

\footnotetext{
${ }^{18}$ Ibid., 73.

${ }^{19}$ Ibid., 73.
} 
means for their production. Regime change entails both the elimination of Saddam Hussein and the Baath Party and the installation of a successor government. These objectives create the aim or focus of the campaign design. ${ }^{20}$

The Iraqi regime depends upon its security forces to ensure the support of the population and the safety of Saddam Hussein. Consequently, severing the link between the dictator and the security forces can undermine the regime. Either killing or seizing the Baath Party leadership or at least its communications with the security system can accomplish that. To achieve the strategic end state, U.S. forces will have to attain control of Baghdad. Baghdad is the center of Iraq's political, economic, and cultural institutions. For a new regime to gain legitimacy, it must control the city.

To secure Baghdad there are four basic options. The first option is similar to the strategy the United States employed in Afghanistan. In Afghanistan, the United States used air power in support of indigenous Afghan forces to defeat the Taliban. In Iraq, the U.S. strategy could be that of a bombing campaign in conjunction with a ground war fought by indigenous forces made up of Kurdish forces and/or turned Iraqi units. The second option is a relatively small U.S. ground force of fewer than 100,000 troops, which isolates Baghdad in much the same manner as Scales describes. The third U.S. option is that of a much larger ground force, perhaps numbering 250,000 troops $^{21}$, which goes into Baghdad and engages in ground combat to sweep the city. A fourth and final option is to attempt to change the regime in Iraq through airpower only. The U.S.

\footnotetext{
${ }^{20}$ President George W. Bush, Press Conference, 6 March 2003, available from http://www.whitehouse.gov/news/releases/2003/03/print/20030306-8.html; Internet, accessed 7 March 2003. Bush said "Well, I hope we don't have to go to war, but if we go to war, we will disarm Iraq. And if we go to war, there will be a regime change. And replacing this cancer inside of Iraq will be a government that represents the rights of all the people, a government which represents the voices of the Shia and Sunni and the Kurds."

${ }^{21}$ Janes, "External Affairs," Iraq; available from http://www4.janes.com; Internet; accessed 2 December 2002.
} 
may combine different elements from each of these strategies to create another option. ${ }^{22}$ For the purpose of this case study, this analysis will combine the second and third options. The U.S. will incorporate the Indirect Approach into a plan that isolates and lays siege to Baghdad with an overall force of 200,000 troops inside Iraq.

Of course, Iraq will also set its objectives and create its plan. Saddam Hussein desires to remain in power as the leader of the current Iraqi government, and to have the potential to achieve regional hegemony over his Arab neighbors. To reach that end state, he must achieve three conditions. First, he must stay in power. Second, his security apparatus must stay loyal and remain in place. The security apparatus is what enables Hussein to keep control over the people of Iraq. Third, he must be able to continue clandestinely creating WMD. Development of a nuclear weapon would better enable Iraq to deter the U.S and to assert control over neighboring nations. The three conditions listed above are already in place in Iraq. Therefore, Hussein simply needs to maintain the status quo to reach his objectives.

Iraq will focus on three U.S. critical vulnerabilities to maintain the status quo and keep the U.S. from winning the conflict. First, he will seek to undermine the coalition. By dissolving the coalition, Saddam would deny the U.S. the use of vital ports, air bases, and terrain in neighboring countries such as Turkey, Saudi Arabia, Qatar, Jordan, and Kuwait. The second of these is international public opinion. If Hussein can influence international public opinion, he will be able to exert pressure on the U.S. to negotiate an end to the conflict. The third critical vulnerability is U.S. domestic opinion. By influencing the U.S. public, Hussein can erode support for the administration and affect the conduct of the war. To strike these critical vulnerabilities, Saddam will entrench himself and his loyal supporters in Baghdad, while he fights his own information campaign against the U.S.

${ }^{22}$ STRATFOR, Iraq War Plans Five-Part Series; available from http://www4.janes.com; Internet; accessed 2 December 2002. 
Intelligence data indicates that Saddam Hussein plans to make the U.S. fight in the cities. "There are some indications that they are going to dig themselves in in population centers," 23 said Walter P. Lang, who was the chief Defense Intelligence Agency analyst on the Middle East during the Gulf War. Mr. Lang also said "Iraqi forces have been digging defensive positions for military equipment around Baghdad." ${ }^{24}$ A statement by a senior Iraqi official further backs these indications. An Iraqi cabinet member, Mohammed Mehdi Saleh, said, "What's in the desert? If they want to change the political system in Iraq, they have to come to Baghdad. We will be waiting for them here." 25 Thus, it is probable that Iraq intends to build its defense on contesting its cities.

Saddam's best-equipped, best trained, and most loyal soldiers will defend Baghdad. The United States will not only face the Special Republican Guard units stationed inside Baghdad, but Republican Guard divisions will likely reinforce those units. At a minimum, the four brigades of the Al Madina Al Munawara Armored Division will defend the outskirts of Baghdad. ${ }^{26}$ The other three divisions in the Northern Republican Guard Corps could also reinforce the Al Madina Al Munawara Division. ${ }^{27}$ Hussein can spread out the units and disperse them throughout the suburbs of Baghdad, making them much more difficult to identify and target.

The campaign must begin by positioning forces. The United States will use Kuwait and its ports to position forces for operations in Iraq. However, major operations cannot begin until diplomatic efforts have been exhausted. How and when the diplomacy ends will have a major

${ }^{23}$ Michael R. Gordon, "Iraq Said to Plan Tangling the U.S. in Street Fighting," New York Times, 26 August 2002, 1 .

${ }^{24}$ Ibid., 1.

${ }^{25}$ Rajiv Chandrasekaren, "Iraqi Officials Plan Urban Warfare," Washington Post, 27 September 2002.

${ }^{26}$ Anthony H. Cordesman, Iraq's Military Capabilities in 2002 A Dynamic Net Assessment (Washington, D.C.: CSIS Press, 2002), 4.

${ }^{27}$ Janes, “Army,” Iraq; available from http://www4.janes.com; Internet; accessed 2 December 2002. 
impact on the shape of the campaign. U.S. airpower will use strategic bombing to hit key targets in Iraq. Close air support and air interdiction will degrade any of Iraq's military forces that remain in the open desert. Special Operations Forces (SOF) will attempt to destroy or neutralize Iraq's weapons of mass destruction. Ground forces will either engage or bypass Iraqi conventional or Republican Guard forces that remain in the open desert. Results from the 1991 Persian Gulf War show that Iraqi forces in the open terrain will probably not pose much of a problem for U.S. forces.

\section{ISR}

At this point in the campaign, those advocating the Indirect Approach try to set certain conditions to avoid direct combat. The U.S. will try to strike important targets such as weapons of mass destruction and the leadership of Iraq's regime and armed forces. The Indirect Approach uses intelligence, surveillance, and reconnaissance (ISR) assets to find targets from a safe distance. ISR is important to the Indirect Approach because it is the key to the indirect destruction of the enemy. To the extent ISR fails, the forces must attack the remaining targets directly. "High-altitude unmanned aerial vehicles orbiting miles above the city could maintain unlimited surveillance with a minimum of manpower. Ground-mounted cameras could observe areas susceptible to infiltration." 28 There are serious issues that prevent these tools from providing unlimited surveillance.

Many military advocates of sensor technology are quick to point out how much sensors have increased the amount of available information. However, sensor assets are not yet capable of providing a full picture of the enemy situation. After his investigation of the war between the U.S. and the Taliban in Afghanistan, Dr. Stephen Biddle made a key observation on the limitations of ISR assets:

\footnotetext{
${ }^{28}$ Robert H. Scales, Jr., Future Warfare (Carlisle Barracks, Pennsylvania: U.S. Army War College, 1999), 183.
} 
At Operation ANACONDA in March 2002, an intensive pre-battle reconnaissance effort focused every available surveillance and target acquisition system on a tiny, ten-by-ten kilometer battlefield. Yet fewer than 50 percent of all the al Qaeda positions ultimately identified in the course of the fighting on this battlefield were discovered prior to contact. In fact, most fire received by U.S. forces in ANACONDA came from initially unseen, unanticipated al Qaeda fighting positions.

How could such things happen in an era of persistent reconnaissance drones, airborne radars, satellite surveillance, thermal imaging and hypersensitive electronic eavesdropping equipment? The answer is that the earth's surface remains an extremely complex environment with an abundance of natural and manmade cover for those militaries capable of exploiting it. ${ }^{29}$

Just as there were limitations to ISR asset capabilities in mountain operations, there will be limitations on ISR effectiveness in Baghdad. Specifically, there are three major factors lim iting ISR.

The first limiting factor is weather, a serious impediment to the use of anything that is flying for surveillance. Not only can poor weather stop aircraft from flying, it also limits the capability of ISR instruments in the aircraft. The second factor is the urban terrain itself. Overhead cover easily blocks aerial surveillance systems. Urban terrain makes it relatively simple to hide or camouflage weapons of mass destruction. An adept enemy can easily use a network of sewers and a series of holes cut through shared walls to maneuver unobserved.

Finally, the large number of civilians in the city will make it very difficult for sensors to pick out the correct leadership targets within the city. Presently, the U.S cannot count on technology to conduct unlimited surveillance of the enemy. As a result, in the Indirect Approach, ISR sensors will often have a difficult time finding the correct target.

Scales suggests that fleeing refugees will provide target intelligence to the U.S. ${ }^{30}$ That suggestion relies on the enemy population, not U.S. capabilities. Refugees may give false information in order to target other ethnic groups or to settle personal vendettas. Iraq could also

\footnotetext{
${ }^{29}$ Stephen Biddle, Afghanistan and the Future of Warfare: Implications for Army and Defense Policy (Carlisle, PA: Strategic Studies Institute), 28-29.

${ }^{30}$ Mark Thompson, “Going Door to Door,” Time, 16 September 2002, 41.
} 
use refugees, either by placing agents among them of giving them misleading information, to plant false intelligence. As a result, U.S. forces could find themselves attacking Iraqi civilians when they believe they are attacking an Iraqi military target. It is very difficult to confirm intelligence without having U.S. forces on the ground inside Baghdad.

Dependency on ISR is potentially a deficiency in the Indirect Approach. Waiting to gain knowledge of the enemy provides the Iraqi regime a sanctuary. Scales writes, "Unless the enemy is attacked, coalition forces will not engage in close combat, instead using greater standoff advantages and technology to strike selected point targets, key leadership, and weapons of mass destruction." 31 Unfortunately, without engaging in close combat or at least threatening close combat by moving units to flush out the enemy, it is difficult to hit enemy forces. Saddam Hussein and his forces could easily find sanctuaries in Baghdad by avoiding the areas that precision fires target. "Iraq knows that the United States cannot bomb schools, mosques, and residential neighborhoods, so it has plenty of places to hide its army." 32 Forces have used this strategy in the past. In Grozny, the Chechens took advantage of the Russians initial concern for civilian casualties by mixing with civilians, and hiding in residences and schools. ${ }^{33}$ U.S. doctrine recognizes this fact. "Recent operations have shown potential adversaries may try to take advantage of the fact that US military forces will comply with the requirements of the law of armed conflict (LOAC)." ${ }^{34}$ In fact, experience has shown that Iraq already knows how to take sanctuary from U.S. precision weapons.

\footnotetext{
${ }^{31}$ Robert H. Scales, Jr., "The Indirect Approach: How U.S. Military Forces Can Avoid the Pitfalls of Future Urban Warfare," Armed Forces Journal International, October 1998, 68-73.

${ }^{32}$ Nicholas D. Kristof, "Fighting Street to Street,” The New York Times, 27 September 2002.

${ }^{33}$ Major Mark Sumner,. "The Case for Joint MOUT Doctrine;" available from http://www.urbanoperations.com/jointdoctrine.htm; Internet; accessed 15 January 2003.

${ }^{34}$ Joint Chiefs of Staff. Joint Publication 3-06, Doctrine for Joint Urban Operations (Washington, D.C.: Joint Chiefs of Staff, 2002), III-8.
} 
During Desert Storm, Saddam and the military and political leadership took refuge in the suburbs, as well as government and corporate buildings that had a low probability of becoming targets. ${ }^{35}$ "The Defense Ministry, for instance, moved into a Ministry of Youth building." 36 Since the Indirect Approach does not provide a way for U.S. forces to engage the enemy with troops on the ground, the Iraqi regime can survive precision targeting form the air, all the while using information operations to weaken the political will of the U.S. and the cohesion of the coalition.

\section{Isolating the City}

Besides conducting ISR during the approach phase, the Indirect Approach requires the isolation of Baghdad. In order to isolate Baghdad, the U.S. must be able to control the movement of military and civilian traffic by air, sea, and land. The U.S. should easily be able to stop movement of Iraqi air assets in and out of Baghdad. Currently the U.S., in conjunction with Great Britain, is enforcing no fly zones in northern and southern Iraq. Establishing another no fly zone around Baghdad will not be difficult. Blocking the navigable channels in and out of Baghdad will also be relatively easy. Shallow draft boats can navigate sections of the Tigris and the Euphrates Rivers. ${ }^{37}$ U.S. Coast Guard or U.S. Navy vessels will patrol the river to ensure only approved traffic goes in and out of Baghdad. The most challenging aspect of isolating Baghdad will be controlling land access to and from the city. U.S. forces can only achieve this efficiently by employing ground forces. These ground forces will be vulnerable to Iraqi direct fire and indirect fire weapons hidden in the city and its suburbs.

\footnotetext{
${ }^{35}$ William M. Arkin, "Baghdad, The Urban Sanctuary in Desert Storm?" Aerospace Power Journal, Spring 1997, 8-10.

${ }^{36}$ Ibid., 10.

${ }^{37}$ Periscope, Nations/Alliances/Geographic Regions Middle East/North Africa- Iraq Last Update 1 October 2002, available from http://www.periscope1.com/demo/nations/mideast/iraq/, Internet, accessed 2 December 2002.
} 
Retaliating against enemy fire is difficult because the Indirect Approach seeks to avoid combat in the city between ground forces. Retaliating in the city and its suburbs with long range and indirect fire weapons means a high risk of civilian casualties. For example, enemy mortars can fire at the cordon from sites near hospitals or mosques, then quickly displace before the U.S.'s answering rounds arrive. The Iraqi government could then publicize the resulting collateral damage. Any effort to isolate Baghdad will encounter this problem but the Indirect Approach exacerbates the problem because it relies on taking as much time as necessary for the city to collapse. As time passes, the cordon stays vulnerable to enemy fire. Therefore, the isolation of Baghdad is possible. However, it is not a risk-free endeavor. Thus, during the approach to Baghdad the Indirect Approach increases the vulnerability of the attacking force to enemy fires and places reliance on ISR to permit precise attacks on the targets within the city. These two conditions may create the political environment Baghdad seeks, namely, an extended attack on the city with the regime still intact.

Once Baghdad has been isolated, regardless of the plan, a decisive phase must ensure to bring about the collapse or destruction of the regime. During this phase, the Indirect Approach calls for U.S. forces to control the city's infrastructure. The course of action uses control, combined with information operations, to cause the people to revolt against the government. U.S forces encourage refugees either to leave the city for camps or to move to areas in the city that will provide them with sanctuary. Humanitarian organizations will then take care of the refugees. According to the Indirect Approach, time is now to the advantage of the U.S.

\section{Infrastructure and Public Services}

Controlling the city's infrastructure depends on two factors. First, the infrastructure must be an important element of the city's life. Second, the U.S. must have the capability to control those systems. 
Perhaps the most important service in Baghdad is electrical power. This is because so many other services rely on power to function properly. The damage to Iraq's electrical network during Desert Storm seriously reduced Iraq's electrical power generating capacity. Iraq's electrical power in 1998 was less than one-half of the 9902 megawatts it could produce before Desert Storm. ${ }^{38}$ A UN report states that current demand in Baghdad is 6200 megawatts, while only 4400 megawatts are available. ${ }^{39}$ As a result, electrical power outages are common in Baghdad. On October 20, 2002, Anthony Shadid of the Boston Globe reported, "[a] half-hour of gusty winds last week disrupted electricity to much of the capital." ${ }^{40}$ On average, the government in Baghdad deliberately cuts off the power for four hours a day to make up for the lack of capacity. ${ }^{41}$ Therefore, the Iraqis frequently endure power outages and disruptions. Nevertheless, any long-lasting denial of power in Baghdad may have far-reaching health effects, especially in the summer, when the average daily temperature is 95 degrees Fahrenheit. Without power, there is no air conditioning or refrigeration. Without these capabilities, the population is more vulnerable to heatstroke and disease.

Electrical power can be targeted in such a way that blackouts will be of short duration. This was the approach used during the Kosovo campaign, when NATO bombed electrical lines with carbon filaments to cause a power outage without inflicting any permanent damage. That is in sharp contrast to Desert Storm, when U.S. forces directly targeted the power plants, which took

\footnotetext{
${ }^{38}$ Janes, "Natural Resources," Iraq; available from http://www4.janes.com; Internet; accessed 2 December 2002.

${ }^{39}$ Anthony Shadid, "War Would Crush Iraqi Cities, Analysts Say,” Boston Globe, 20 October 2002, 1.

${ }^{40}$ Ibid., 1.

${ }^{41}$ United Nations, "Portrait of the Current Socio-Economic Developmental Situation and Implications in Iraq based on Specified Scenarios," 20 January 2003, 7; available from http://www.casi.org.uk/info/undocs/un030120.pdf; Internet; accessed 14 February 2003.
} 
months and years to repair. ${ }^{42}$ Therefore, U.S. forces will have some degree of control over how long it will take to bring back electrical service to Baghdad.

The power outages of Desert Storm are largely responsible for the current state of repair of Baghdad's wastewater treatment system. Baghdad's wastewater relies on pumps to move it through the pipes. Without electricity, the pumps do not run, and the static wastewater corrodes the pipes. As a result, there were "18,000 pipes' settlements and breaks during 1990-1997 compared to only 18 during the period 1985 to $1990 . " 43$ Sewerage disposal in Baghdad is unreliable and, in some areas, non-existent. Saddam City, a suburb of Baghdad, has only twothirds of its sewage treated; the rest runs in the streets through canals the residents made out of trash. ${ }^{44}$ Further denial of sewage disposal is unlikely to have a large impact on the population of Baghdad. However, the denial of drinking water will have a large impact.

The citizens of Baghdad have seen the quantity of potable water cut in half in the last decade. Treatment of surface water is necessary in Iraq because approximately one-quarter of the population runs their raw sewage into open water sources. ${ }^{45}$ In Baghdad, the number of liters of potable water per day has dropped from 330 in 1991 to 150 in $2000 .{ }^{46}$ The poor quality of the distribution network results in a bss of $35 \%$ of the potable water, while "illegal connections and misuse has resulted in 50 percent of water produced being unaccounted for in Baghdad City alone." ${ }^{47}$ If the U.S. cuts off drinking water supplies in Baghdad, distribution of the remaining

\footnotetext{
${ }^{42}$ Anthony Shadid, "War Would Crush Iraqi Cities, Analysts Say,” Boston Globe, 20 October 2002, 1.

${ }^{43}$ Joint Government of IRAQ- UNICEF Programme Review 1990-2000, 9; available from http://www.unicef.org/iraq/library/join-1/reports.htm; Internet; accessed 2 December 2003.

${ }^{44}$ Anthony Shadid, “War Would Crush Iraqi Cities, Analysts Say,” Boston Globe, 20 October 2002, 1.

45 Joint Government of IRAQ- UNICEF Programme Review 1990-2000, 6; available from http://www.unicef.org/iraq/library/join-1/reports.htm; Internet; accessed 2 December 2003.

${ }^{46}$ Ibid., 6.

${ }^{47}$ Ibid., 8-9.
} 
potable water will go to Baghdad's elites and security organizations. The rest of the population will be at great risk of disease.

U.S. forces can largely deny clean drinking water and wastewater by taking out the electricity in Baghdad because "70\% of water projects in Iraq have no functioning backup generator." 48 Furthermore, since the piping network itself relies on electrical pumps rather than just gravity, an electrical failure will interrupt the collection and disposal of wastewater, as it did in Desert Storm. ${ }^{49}$ It will be unnecessary and inadvisable to destroy the plants themselves, because the damage will be costly to restore. Another sanitation service, garbage disposal, is more difficult for U.S. forces to control. However, sanitation services are already very poor.

The state of garbage collection and disposal services in Baghdad is atrocious. The numbers of garbage trucks in Baghdad have declined from 800 in1990 to 480 in 2000. The result is that two-thirds of the garbage that Baghdad produces now accumulates between the residences of Baghdad. An interruption of garbage disposal will only increase the pace that garbage is accumulating by $33 \%$.

It will also be difficult for U.S. forces to control garbage removal. The system has no central nodes to target. Bombing a landfill may disperse its contents, but it does not eliminate its use as a dumpsite. However, the disposal system is in such a poor state, there really is not much of a need or benefit to controlling it.

Another system that is very difficult to control is the media. There is a great deal of debate about whether U.S. forces can and should control the media during urban operations. Like Scales, Dov Tamari, a retired brigadier general who served in the Israeli Defense Forces during the Lebanon Campaign, believes that forces involved in urban operations should control the media. He writes, "Internal and external isolation are very beneficial, and only carefully selected

\footnotetext{
${ }^{48}$ Ibid., 8.

${ }^{49}$ Ibid., 9.
} 
information should be released for publication." ${ }^{50}$ Tamari suggested modeling a media campaign after the method the U.S. used during Desert Storm. However, during Desert Storm, U.S. forces were unable to control the international media in Baghdad. Nor did the bombing of Baghdad completely drive away the media.

"Controlling both news representatives and their information is complicated by the nature of city environments." ${ }^{51}$ With the most intriguing story in the world unfolding in Baghdad, it will be close to impossible to keep the media out. Enterprising journalists will find ways to embed themselves in the city, and, if necessary, will be equally creative in smuggling their stories out through refugees or humanitarian and non-governmental organizations. The media will most likely be impossible to control.

A new weapon that the U.S. may use for the first time in Iraq is the microwave bomb. These bombs are capable of destroying computers without causing other collateral damage. ${ }^{52}$ However, according to the editor of Jane's Air-Launched Weapons, Rob Hewson, the weapon will have little control, rather, "it would be indiscriminate, not just turning off electricity for Iraq's radar stations, but also affecting power to hospitals and schools." ${ }^{53}$ The only degree of control the weapon offers is that it may allow the U.S. to take out some parts of the infrastructure, such as wastewater treatment plants, without physically destroying the structure of the plants.

U.N. sanctions have already produced a shortage of food for the Iraqi people. Estimates made in 1993 showed that the average Iraqi diet had only 2250 calories available to consume, as

\footnotetext{
${ }^{50}$ Dov Tamari, "Military Operations in Urban Environments: The Case of Lebanon, 1982," in Soldiers in Cities: Military Operations on Urban Terrain, ed., Michael C. Desch (Carlisle, PA: Strategic Studies Institurte, 2001), 51.

${ }^{51}$ Russell W. Glenn, “...We Band of Brothers” The Call for Joint Urban Operations Doctrine. Santa Monica, CA: RAND, 1999, 38.

${ }^{52}$ Robert Schlesinger. "US readying launch of high-tech attack,” Boston Globe, 23 January 2003.

${ }^{53}$ Michael Evans, "Why Any War With Iraq Will Be Over In A Flash" London Times, 24 December 2002.
} 
opposed to 3000 calories before Desert Storm. ${ }^{54}$ The government of Iraq rations UN provided food, but by no means does every citizen get an equal share. ${ }^{55}$ In fact, the "regime has also been accused of manipulating food rationing to bolster its position" ${ }^{, 56}$ over the population. In a recent report, the United Nations wrote, the "Iraqi regime has been able to tighten its grip on the people through a system of rationing and indirectly through the oil-for-food programme, enabling the central authorities to reward loyalty and punish dissent." ${ }^{57}$ If U.S. forces cut off the food supplies to Baghdad, canned and preserved foods stockpiled in Baghdad are likely to go to the elite and the security forces, while the great majority of civilians starve.

Denying food to the Iraqi people will be relatively easy for the U.S. The vast majority of Iraq's food now comes from the UN oil-for-food program. Turning off or redirecting the supply will be easy when the U.S. controls the approaches to Baghdad. However, denying food is not the same thing as controlling it. The U.S. will not be able to determine which of Baghdad's citizens eat and which do not. Iraq's security forces will be in a much better position to accomplish that.

The issue of control and denial applies not just to food, but also to all of the infrastructure and service systems discussed above. U.S. forces will not be able to control infrastructure and public services in Baghdad, but they will be able to destroy infrastructure and deny those services for some duration. The term control implies that U.S. forces could use technological means to turn utilities and services on and off at will. Clearly, that degree of control was not available

\footnotetext{
${ }^{54}$ Janes, "Natural Resources," Iraq; available from http://www4.janes.com; Internet; accessed 2 December 2002..

${ }^{55}$ Ibid.

${ }^{56}$ Janes, "External Affairs," Iraq; available from http://www4.janes.com; Internet; accessed 2 December 2002.

${ }^{57}$ United Nations, "ECPS 'Portrait of Iraq (Draft)," 7 January 2003, 1, available from http://www.casi.org.uk/info/undocs/ecps030107.pdf; Internet; accessed 14 February 2003.
} 
during Desert Storm. Desert Storm's results showed that the coalition was easily able to take out infrastructure and public services.

The United Nations Children's Fund (UNICEF) stated immediately after the ceasefire that Baghdad 'is a city essentially unmarked, a body with its skin basically intact, with every main bone broken and with its joints and tendons cut...' There was little rubble, and civilians were spared, but their life support systems- electricity, water, transportation, communications- were disabled. ${ }^{58}$

However, there is little evidence that coalition forces were able to control these services and utilities to any degree beyond turning them off. Technological advances since Desert Storm has done little to advance that control, with some exceptions, such as inducing temporary electrical outages without causing permanent damage.

Control is the wrong term for the power U.S. forces will have over Baghdad's utilities and services. Deny is a better word. U.S. forces will only be showing that they have shut down Baghdad, not that they control Baghdad. The distinction is important, for the population will not see the U.S. as in control of their life support systems; instead, the population will only see that no one is in control of those systems.

The denial of public services and infrastructure will not have a large effect on the survival of the Baath Party elite and the security forces in Baghdad. Instead, it will further degrade the miserable conditions that the rest of the population endures. Almost one-third of the population "lives in slums and squatter settlements." fresh water and some urban areas are ankle deep in raw sewage. Food is scarce and many Iraqis are struggling to survive." ${ }^{60}$ The specific data on the power, food, water, and sanitation services reveals that the majority of the population of the city will endure the worst of the service

\footnotetext{
${ }^{58}$ William M. Arkin, "Baghdad, The Urban Sanctuary in Desert Storm?" Aerospace Power Journal, Spring 1997, 3 . 2002.

${ }^{59}$ Janes, "Demographics," Iraq; available from http://www4.janes.com; Internet; accessed 2 December

${ }^{60}$ Ibid.
} 
interruptions, while the elite will live off the resources that they have husbanded and that remain available.

After considering the prospects for controlling the infrastructure of Baghdad, two conclusions stand out. First, the services are currently so poor that the effects on the populace and their support for the regime are likely to be minimal in military terms. The increased suffering, however, may improve the regime's international political efforts. Second, the United States can gain control of the major urban service, electrical distribution, but controlling any or all of the other services does not seem significant. Thus, the first assumption of the Indirect Approach, namely that civilian hardship will lead to discontent, seems questionable.

The Indirect Approach calls for control of the infrastructure, combined with information operations, to cause the population to overthrow the government. Two parts of that premise warrant further examination. The first is the capability of information operations to foment a revolution. The second is whether the population is capable of overthrowing the government.

\section{Information Operations}

The United States and Iraq are already using information operations to influence the Iraqi people. For example, Radio Sawa, a U.S. radio station that broadcasts over the radios of the Iraqi people, featured a message "from the Pentagon's No. 3 official urging Iraqis to rise up against the dictator." ${ }^{61}$ In Scales' proposed course of action, U.S. forces will use leaflet drops and other methods to send the same message to the population of Baghdad. The challenge that the U.S. will face is convincing the very population that the U.S. is laying siege to that foreign control, however temporary, will be a better alternative than the current Iraqi regime.

“"Baghdad is one of those cities that happen to contain all the kindling necessary to spark a revolt" says Scales. "You'd have the ruling elite and the army cheek by jowl with the people,

\footnotetext{
${ }^{61}$ Eli J. Lake, “U.S. Takes To Air To Topple Saddam,” Washington Times, 24 August 2002, 1.
} 
who despise both the elite and the army." 62 This statement is a sociological judgment, the proof of which is impossible. The Iraqi people will probably not revolt against their ruler. Data on the current conditions in Baghdad, as well as historical evidence, back the assertion.

The information operations that the current Iraqi regime is already conducting will make it all the more difficult for the U.S. to succeed in getting its message across. Major General Saad Obeidi, an Iraqi defector who fought against the U.S. during Desert Storm, said that an attack on the Iraqi infrastructure similar to the one that the U.S. conducted in Desert Storm would bolster Saddam's support from the Iraqi people. ${ }^{63}$ GEN. Obeidi said, "Saddam is trying to condition the Iraqi people that the coming attack is targeting them as well as him; that the United States is trying to destroy Iraq's past and future." ${ }^{64}$ Saddam has made it clear to all Iraqis that the U.S. is responsible for the scarcity of food, clean water, and other vital resources in Iraq. ${ }^{65}$ That message is so important to Saddam that U.S. intelligence analysts believe Saddam may take out some of Iraq's key infrastructure and blame U.S. forces. ${ }^{66}$ Denying services in Baghdad and further degrading the population's quality of life will bolster Saddam's message.

Iraq will also have the home team advantage in information operations. The U.S. will look like the aggressor when it crosses Iraq's borders and invades. That appearance will make a strong impression on the Iraqi population and the international community, and Saddam will make good use of it in his information operations. To boost the appearance of U.S. aggression, it

\footnotetext{
${ }^{62}$ Mark Thompson, "Going Door To Door Saddam Hussein hopes to engage Americans in street fighting in Baghdad, a scenario the U.S. wants to avoid," Time, 16 September 2002, 41.

${ }^{63}$,Khaled Yacoub Oweis, “Iraqi Mistrust a Way of Life,” Reuters News Agency.

64 Ibid.

65 Janes, Executive Summary, Iraq, available from http://www4.janes.com; Internet; accessed 2 December 2002..

${ }^{66}$ Associated Press, "Saddam set to ruin infrastructure, blame U.S." The Washington Times, 19 December 2002.
} 
is very likely that Iraq will shield U.S. targets with civilians. ${ }^{67}$ Civilian casualties will increase international pressure to end the war and further alienate the Iraqi population from the U.S. ${ }^{68}$

It is very difficult to estimate how much resistance there is in Baghdad that could stand up to the regime. Whether the people will revolt against the Baath Party and its tightly held security apparatus is really a sociological judgment. Interviews with Iraqi exiles give an anecdotal view of the difficulty of predicting the amount of revolutionary fervor. Sharif Ali bin Hussein, who is part of the old Iraqi monarchy, said, "There is nobody left in Iraq who believes in Saddam Hussein. They only fear his apparatus of terror." ${ }^{69}$ Anas Shallal, another Iraqi who lives in America and still has relatives in Iraq, says "The U.S. pressure, whether through sanction or support of these [Iraqi Exile] groups, is only making people rally around Saddam's regime, even if they don't like him personally." 70 Even with extremely detailed local knowledge and a team of anthropologists, it is impossible to predict and count on a revolution as part of a course of action.

Therefore, it is by no means clear that information operations will motivate the population of Baghdad to overthrow the current regime. The U.S. will have a difficult time getting its message across, particularly when laying siege to Baghdad. Saddam has designed his message around the destruction of the Iraqi infrastructure and the degradation of the Iraqi people's quality of life. The Indirect Approach will reinforce his message that the U.S. is hurting the Iraqi people, and not just the Iraqi regime.

Historical data indicates that coup attempts against Saddam Hussein have been very few and completely unsuccessful. A palace coup is unlikely after 33 years of power during which

\footnotetext{
${ }^{67}$ Janes, “Armed Forces,” Iraq; available from http://www4.janes.com; Internet; accessed 2 December 2002.

${ }^{68}$ Ibid.

69 "Iraqi Exiles Divided On Future Differ over plans after Saddam," Washington Times, 30 August $2002,1$.

${ }^{70}$ Ibid, 1.
} 
Saddam has "perfected the art of personal survival." 71 There were reports that an element of the Republican Guard attempted a coup in 1992, but that Special Republican Guard units and security forces in Baghdad stopped it almost immediately. ${ }^{72}$ It is unlikely, "based on Saddam's past survival, improved ability to buy support and pay off elites, and decade-long experience in purging its enemies," that an internal Iraqi coup will be successful in Baghdad. ${ }^{73}$ Historically, hurting the population of a nation does not endanger that nation's government. Instead, it tends to cause resentment and resistance against the attacker. "Punishment does produce emotional stress, but this reduces rather than increases collective action against the government, because heavy punishment induces a "survival" response and light punishment, a "Pearl Harbor" effect.,"74

Even if the population made the effort to revolt, it is unlikely that a true revolution will occur in Baghdad. For regime change to take place, someone who is not in Saddam's inner circle will have to take over the country. Otherwise, the resulting Iraqi regime will probably look a lot like the previous regime. In addition, the forces that Saddam has assigned to defend Baghdad are the ones that are most loyal to the regime. Many of these soldiers and intelligence agents have killed Iraqi citizens for Saddam. ${ }^{75}$ They are unlikely to revolt, for they fear revenge and prosecution at the hands of their fellow citizens.

Finally, if the population did revolt, it will be extremely difficult for them to win against Saddam's Special Republican Guard and security apparatus. While the siege will have detrimental effects on the entire population, Saddam would surely divert food, clean water, and

${ }^{71}$ Tim Ripley, “Strategies For Iraqi Regime Change,” Janes Intelligence Review, September 2002, 32.

${ }^{72}$ Anthony H. Cordesman, Iran \& Iraq, the Threat from the Northern Gulf (Boulder, Colorado: Westview Press, 1994), 123.

${ }^{73}$ Anthony H. Cordesman, "If We Fight Iraq: The Lessons of the Fighting in Afghanistan" (Washington, D.C.: CSIS, 7 Dec 2001), 5.

${ }^{74}$ Robert A. Pape, Bombing to Win: Airpower and Coercion in War (Ithaca: Cornell University Press, 1996), 25.

${ }^{75}$ Sydney J. Freedberg,, Jr., "Military Planners ponder the unknowns in Iraq," National Journal, October 25, 2002, 9. 
health care to his most loyal forces. Those who benefited from the disproportional distribution will gain in relative strength vs. the rest of the population during a siege. The longer the siege goes on, the more difficult it will be for the Iraqi people to revolt. Therefore, U.S. control of infrastructure, combined with information operations, will probably not make the Iraqi people overthrow their ruler or cause Iraqi forces to surrender. The U.S. will not be able to control infrastructure and services, but rather, will simply be able to deny them. That denial will have the main effect of making the majority of the population of Baghdad more destitute relative to Baghdad's elite. In turn, the destruction of the infrastructure will bolster Saddam Hussein's information operations while weakening the strength of the U.S. forces' message. If the population were to revolt, it is unlikely to succeed, due to the strength of the opposition, and the relative weakness of the majority of the population due to the siege. Consequently, because the Indirect Approach relies on a popular revolt to topple the regime, the method appears to leave decisive action to others.

\section{Refugees}

Although the population is unlikely to revolt, it is likely that a large part of the population will leave the city. The Indirect Approach calls for encouraging refugees to leave the city for camps or to go to a safe area of the city where they can get humanitarian aid. In the case of Baghdad, establishing a safe haven in the city would certainly require U.S. forces to secure the area. That would involve clearing any portion of the city from which direct or indirect fire could attack the safe haven. U.S. forces could only accomplish that by clearing a major portion of the city. The Indirect Approach seeks to avoid that task. Therefore, the refugees would have to leave Baghdad.

Any U.S. military operation in Iraq will cause the migration of refugees from one place to another. Some of these refugees will seek asylum in neighboring countries, others will become internally displaced persons (IDPs) within Iraq. Depending on the admissions policy of the 
country in which they seek refuge, asylum seekers may end up pinned on the Iraq side of the border. Initial estimates of the UN indicate that there will be between 566,000 to $1,400,000$ asylum seekers, in addition to 2,000,000 internally displaced persons. ${ }^{76}$ The total maximum estimate of 3.4 million refugees is a considerable portion of the 25.5 million ${ }^{77}$ people estimated to populate Iraq in October 2002. Nevertheless, if coalition forces use the Indirect Approach, these numbers will almost double.

The result of the Indirect Approach will be a far greater number of refugees fleeing the Baghdad area. This is because U.S. forces will actively encourage the population of the city to flee. ${ }^{78}$ The population of Baghdad is approximately 5 million people ${ }^{79}$. Current UN estimates for IDPs from the Baghdad area are 550,000. 280,000 would be a very liberal estimate of the number of asylum seekers that the UN believes will depart Baghdad. ${ }^{80}$ That totals 830,000 refugees that the UN estimates will depart the Baghdad area. The Indirect Approach would probably result in at least $80 \%$ of the population departing Baghdad, or over 4 million refugees. That is over four times UN estimates. The course of action will increase the number of refugees departing Baghdad four-fold and almost double the number of IDPs and asylum seekers in Iraq. The logistical implications for caring for these numbers are profound. Scales solves the problem by

\footnotetext{
${ }^{76}$ Office for the Coordination of Humanitarian Affairs, United Nations, "Integrated Humanitarian Contingency Plan for Iraq and neighboring Countries," Working Draft, 7 January 2003, 9-11; available from http://www.casi.org.uk/info/undocs/ocha030107.pdf; Internet; accessed 14 February 2003.

${ }^{77}$ Countrywatch, Iraq 2003 Country Overview, 1, available from www.countrywatch.com, Internet, accessed 2 December 2002.

${ }^{78}$ Robert H. Scales, Jr., Future Warfare, 184.

79 Janes, "Demography," Iraq; available from http://www4.janes.com; Internet; accessed 2 December 2002..

${ }^{80}$ It is not clear from the source document how many of the asylum seekers in the UN estimates will originate from the Baghdad area. This monograph arrives at an estimate of the figure using the following analysis: Baghdad makes up approximately $20 \%$ of the Iraqi population. $20 \%$ of the 1.4 million asylum seekers is 280,000. Since 1.4 million is the high end of the range of asylum seekers $(566,000$ to $1,400,000), 280,000$ is probably a liberal estimate of the portion of asylum seekers that the UN thought would come from Baghdad.
} 
assuming "Humanitarian organizations, both governmental and non-governmental, will be encouraged to construct protected camps." ${ }^{81}$ Unfortunately, the U.S. cannot count on the proficiency of these organizations. The war will make scarce the very resources that the organizations utilize to bring food and shelter to refugees. Bridges may be out; military forces and displaced persons will clog the roads; and vehicles and fuel will be scarce.

In addition, U.S. military forces will need to divert scarce theater and national assets to support the organizations working with the refugees. U.S. Joint Doctrine warns against the effects this support can have on military campaigns: "Support to noncombatants, if required, may strain the ability to support U.S. forces, allies, regional governments, nongovernmental organizations (NGOs) and international organizations." ${ }^{82}$ The same ports, airfields, and lines of communication that U.S. military forces utilize to conduct the war are the very resources that humanitarian organizations need to care for civilians. Humanitarian organizations have come to expect engineering and logistics support from the U.S. military. ${ }^{83}$ In any campaign plan involving Iraq, it will be necessary for U.S. forces to support refugees. However, it is usually in the best interests of the campaign to keep the number of refugees down. Then U.S. forces can focus their assets on fighting the campaign while minimizing human suffering.

The refugee crisis also raises another humanitarian issue: The plight of those who stay in the city. Those who will need to flee the crumbling infrastructure the most, such as the elderly, the hospitalized, and the mobility impaired, will be the least able to do so. Others will simply choose to stay in Baghdad. The Iraqi government will almost certainly seize the plight of these people for its media effect. The true burden for taking care of those who stay in the city is not on

${ }^{81}$ Robert H. Scales, Jr., Future Warfare, 184.

82 Joint Chiefs of Staff. Joint Publication 3-06, Doctrine for Joint Urban Operations, II-3.

${ }^{83}$ United Nations, Likely Humanitarian Scenarios, 10 December 2002, 12; available at http://www.casi.org.uk/info/undocs/war021210scanned.pdf; Internet, accessed 14 February 2003. 
the Iraqi regime, as the Indirect Approach suggests. ${ }^{84}$ The burden is on the United States. After taking away food and clean water from the residents of Baghdad, it will be difficult to sell the international community and the media on the idea that the suffering of Baghdad's residents is the Iraqi government's problem.

Saddam Hussein may not allow his people to leave Baghdad. He "has a history of manufacturing humanitarian crises." ${ }^{85}$ Scales argues, "If the enemy keeps them contained inside the city, then he becomes the bad guy in the eyes of his own people because he can no longer sustain them." 86 This may not be true. Saddam could force the population to remain in the city while spreading propaganda about U.S. forces slaughtering refugees. In any case, if the population remains in the city while the U.S. lays siege to it, the U.S. will have a difficult time explaining the necessity of the massive civilian suffering. Having more civilians in the city also benefits Saddam because it enables his forces to blend in with the population and makes it more difficult for U.S. forces to avoid civilian casualties. For political, military, and diplomatic advantage, it will be in Saddam's best interest to keep the population in Baghdad.

The humanitarian crisis will create enormous domestic and international political pressure to end the siege prematurely. If deaths occur among the refugees, U.S. domestic support may quickly suffer. "A recent New York Times/CBS News poll indicated that support for using military action to depose Mr. Hussein would fall by 20 percentage points, to 46 percent, if a substantial number of Iraqis died." 87

\footnotetext{
${ }^{84}$ Robert H. Scales, Future Warfare, 184.

${ }^{85}$ Steve Hadley, "The Plan for a Postwar Iraq," Washington Post, 28 February 2003. Hadley is President Bush's Deputy National Security Advisor.

${ }^{86}$ Robert H. Scales, Jr., "A MOUT Doctrinal Concept," in The City's Many Faces, Proceedings of the RAND Arroyo-MCWL-J8 UWG Urban Operations Conference, ed. Rusell W. Glenn (Santa Monica, CA: RAND, 2000), 165.

${ }^{87}$ James Dao, “U.S. Plan: Spare Iraq’s Civilians,” New York Times, 23 February 2003, 1.
} 
International political pressure to end the siege will increase significantly due to humanitarian considerations. "High levels of civilian casualties, or the perception of civilian casualties, could lead to an international diplomatic outcry to end the war prematurely." 88 Pressure will begin almost immediately with the siege operation. The plight of the refugees and the city's inhabitants will focus world attention. The consequences of the humanitarian crisis will erode the legitimacy of the United States' case for a war, and affect the support that other nations give the coalition. Thus, the humanitarian crisis will hurt the U.S. case for the war, divert vital military resources, and possibly force a premature end to the siege. Granted, virtually any military action in Iraq will create refugee movements and temporarily interrupt the shipment of vital resources to the citizens of Iraq. However, U.S. forces must be careful to choose a course of action that minimizes the impact, rather than one that intentionally increases the impact.

\section{Time}

The key idea in the Indirect Approach is that time is on the side of the U.S. However, this case study shows that time is not on the side of U.S. forces besieging Baghdad. Instead, the passage of time will actually favor Saddam Hussein. Saddam's first goal is to remain in power. The longer the conflict drags on, the greater the chance that Saddam will be able to do that. Three major factors will increase Saddam's chances of remaining in power as the conflict drags on. These factors directly correlate with the three critical vulnerabilities that Iraq is trying to exploit: The cohesiveness of the coalition, international public opinion, and U.S. domestic public opinion.

The first factor is the effect that the conflict will have on other governments in the Middle East. "Saddam realizes that a U.S. attack would put many Arab regimes under serious strain as it would inevitably result in massive and destabilizing anti-U.S. demonstrations across the

\footnotetext{
${ }^{88}$ Ibid, 1.
} 
region." 89 The longer the conflict goes on, the more it will stir up resentment, possibly causing the U.S. to lose the support of vital bases and resources in the region.

The second factor is domestic public opinion in the U.S. As the conflict in Iraq goes on, debate over the conduct and necessity of the war will continue in the U.S. Should the conflict continue long enough, the results of U.S. elections may reflect the level of support for the war. The third factor is international pressure to end the conflict. The appearance of a stalemate in Baghdad will cause many nations to urge the U.S. to negotiate with the regime in Baghdad, a lesson that the Russians learned in Grozny. "Long-term engagement works against the intruding force; as civilian casualties mount, every move is scrutinized in the media, and the international community bands together to scold the "perpetrator." 90 Many proposals will be made that may not match U.S. interests, such as allowing Saddam to stay in power, provided that he disarm and submit to close monitoring, much as the treaty at the end of the Gulf War stated.

MG Scales believes that from a purely military point of view, the longer U.S. forces wait to clear Baghdad, the better. However, as Wass de Czege and Sinnreich wrote in Conceptual Foundations of a Transformed U.S. Army, "cities are vital natural resources, and their prompt liberation or seizure easily can become a political imperative."91 Due to the destabilizing effect the conflict will have on neighboring Arab nations, the importance of U.S. public opinion leading up to elections, and pressure from the international community, U.S. forces will be under intense domestic and international political pressure to complete operations in Baghdad sooner rather than later. Time is not on the United States' side.

\footnotetext{
${ }^{89}$ Janes. "Executive Summary," Iraq; available from http://www4.janes.com; Internet; accessed 2 December 2002.

${ }^{90}$ Timothy L. Thomas, "The Battle of Grozny: Deadly Classroom for Urban Combat.” Parameters, Summer 1999, 87-102.

${ }^{91}$ Huba Wass de Czega, and Richard Hart Sinnreich, Conceptual Foundations of a Transformed U.S. Army, the Land Warfare Papers \# 40 (Arlington, VA: AUSA, March 2002), 16.
} 
The United States does not have a clean mechanism to produce the Iraqi regime's fall. Nevertheless, assuming it works, the outcome must "not conflict with the long-term solution to the crisis." ${ }^{92}$ It is important to examine the outcome of the Indirect Approach against the U.S.'s desired end state and objectives. As defined earlier, that end state is a new representative government in Iraq $^{93}$ that possesses no weapons of mass destruction (WMD) and is not a threat to the United States. ${ }^{94}$ To achieve that end the United States needs to topple the existing regime and locate and destroy weapons of mass destruction and the means to produce them. ${ }^{95}$

The Indirect Approach seeks to achieve the first objective, to end the power of the old regime, through an overthrow of the government by the people or through a surrender of the old regime. The U.S. will attempt to cause the overthrow or surrender with a siege and precision targeting. The approach proposes to allow time to pass until the method works. This approach allows no means to determine if the method has failed. If there is no surrender or revolution, then perhaps U.S. forces simply need more time. Conceivably, the U.S. may not reach the first military objective, and instead, a stalemate will occur.

The second objective is the creation of a new regime to control Iraq. In Baghdad, the new regime will need to provide the people with a working infrastructure and dependable public services. Those actions will help the government to convince the people that it is legitimate. Unfortunately, the Indirect Approach works against this end state by deliberately targeting infrastructure and public services. Tamari wrote of the long-term effects from the destruction of infrastructure:

92 Joint Chiefs of Staff. Joint Publication 3-0, Doctrine for Joint Operations, III-21.

93 Judy Keen, “Code Phrase Gets Retooled For Saddam,” USA Today, 27 August 2002, 11.

${ }^{94}$ President George W. Bush, Press Conference, 6 March 2003, available from http://www.whitehouse.gov/news/releases/2003/03/print/20030306-8.html; Internet, accessed 7 March 2003.

${ }^{95}$ Ibid. 
On numerous occasions, we attacked and destroyed physical infrastructure elements within the area of influence in order to exert pressure on the opponent and his interests. Such infrastructure elements included bridges, transportation, power stations, etc. In the short term, this course of action may have been beneficial. In the long run, however, its benefits are doubtful, as the purpose of our intervention was to make peace and restore stability—and it is very difficult to accomplish this in a country or an area whose infrastructure we have destroyed. ${ }^{96}$

The same issues that applied to the Israelis in Lebanon will apply to the U.S. in Iraq. Steve Hadley, the U.S. Deputy National Security Advisor, wrote recently that after the conflict "Early efforts will include restoring electricity and clean water..."97 Deliberate destruction of infrastructure may be necessary for certain military operations. However, when planning the campaign with a view of the end state in mind, it is clear that targeting infrastructure should be a last resort.

The third objective requires the U.S. to destroy Iraq's WMD and WMD program. The Indirect Approach suggests striking these targets with precision weapons. Unfortunately, as discussed earlier, it is relatively easy to hide weapons in an urban area. It is also difficult for ISR assets to find them. Because the Indirect Approach does not call for U.S. forces to be on the ground in the city, a good accounting and destruction of WMD cannot take place until after the city falls. This will leave U.S. forces and the Iraqi population more vulnerable to WMD during the siege.

The ultimate objective that extends beyond Iraq is the transfer of loyalty and support by the people to the new regime. If the U.S. implements a siege, it will not just be fighting the regime of Iraq, but the people of Iraq. As Tamari wrote when reflecting on the lessons learned from Israel's campaign in Lebanon, "It is important that we distinguish the opponent- be it the

\footnotetext{
${ }^{96}$ Dov Tamari, "Military Operations in Urban Environments: The Case of Lebanon, 1982," in Soldiers in Cities: Military Operations on Urban Terrain, Ed., Michael C. Desch (Carlisle, PA: Strategic Studies Institurte, 2001), 51.

${ }^{97}$ Steve Hadley, “The Plan for a Postwar Iraq,” Washington Post, 28 February 2003.
} 
regime, the military leadership, or the military forces- from the civilian population." ${ }^{98}$ This distinction proved important to the Israelis because they lost a lot of ground in winning the peace when they deferred taking care of the civilian population until after they had finished fighting the armed forces. "The damage we caused by our military operation was very difficult to repair or make up for during the next phase." 99 The United States will run into the same problem if it conducts a siege of Baghdad in which the Iraqi civilian population suffers immensely. The people will be unlikely to take a favorable view of the U.S. or of the government that the U.S. installs.

Therefore, The Indirect Approach fails to fit in well with the end state that the U.S. desires. There is no decisive operation to ensure that the old regime will fall. Destruction of the infrastructure will make it difficult for a new government to gain control of Baghdad. U.S. forces cannot bring all of their power to bear against weapons of mass destruction until after the city falls. Two of the keys to successfully installing a stable, peaceful regime that shares U.S. interests is winning over the population and preserving the infrastructure. Scales' approach works against achieving both of those key factors.

\section{CHAPTER FOUR: CONCLUSIONS AND RECOMMENDATIONS}

There are several practical reasons why the Indirect Approach will fail. First, time is not on the side of the U.S. if it lays siege to Baghdad. International media will cover the suffering among Baghdad's population. That coverage will create international and domestic political pressure to lift the siege. The U.S. might then have to lift the siege prematurely, before regime change takes place.

\footnotetext{
${ }^{98}$ Dov Tamari, "Military Operations in Urban Environments: The Case of Lebanon, 1982," in Soldiers in Cities: Military Operations on Urban Terrain, Ed., Michael C. Desch (Carlisle, PA: Strategic Studies Institurte, 2001), 51.

${ }^{99}$ Ibid, 51.
} 
Second, U.S. control of infrastructure and information operations will neither lead the Iraqi people to overthrow their ruler, nor will it cause Iraqi forces to surrender. The U.S. will not be able to control Baghdad's infrastructure and public services to the degree that Scales suggests. Instead, military action will simply create outages of varying duration. The Iraqi people who can most easily lead a coup are members of the Baath Party and in the security forces close to Saddam. These same people will be the least effected by service outages. Saddam will continue to siphon resources from the rest of Baghdad's population to take care of these elites. Thus, U.S. military control of services cannot influence the Iraqi elite to lead a coup. Because the larger Iraqi population is dependent on the regime, they will probably not be able to gain the access needed to topple Saddam Hussein. Saddam Hussein has ruled by murdering or imprisoning any who show opposition or disloyalty to his regime. These conditions do not support the organization of revolution among his citizens. Even if the Iraqi people did attempt to dislodge the Baath Party from power, it is even less probable that they would succeed. Instead, Iraqi citizens are likely to suffer under Saddam's leadership until outside forces remove him from power.

A phenomenal humanitarian crisis will result from MG Scales' proposal. A city is a life support system for the population within it. The siege will cut off the life support, and, if the Iraqi regime allows it, the majority of the population in Baghdad will flee. The Indirect Approach calls for U.S. forces to encourage the population to leave the city. ${ }^{100}$ The U.S. will then have to find a way to care for millions of Iraqi civilians. A further problem is that the very people who are unable to flee the city, such as the elderly, mobility-impaired, and the hospitalized, are most in need of special care. The refugee problem will distract U.S. forces from their primary mission and cause further domestic and international political pressure to end the siege.

ISR assets will not be able to find all of the enemy targets in the city. It is easy to conceal weapons and WMD in urban areas. Enemy leaders and soldiers can blend in with the civilian

${ }^{100}$ Robert H. Scales, Jr., Future Warfare, 183-184. 
population. Weather will prevent ISR assets from being able to conduct continuous surveillance. As a result, precision fires will not be able to find and strike all of the necessary targets.

Using precision fires, without at least the accompanying threat of direct force on the ground, has the effect of creating sanctuaries for Saddam Hussein and his forces. Iraqi intelligence organizations can easily assess what targets the U.S. will and will not strike. Iraqi forces and leadership can take refuge in residential areas, hospitals, and mosques. U.S. forces may only be able to clear those sanctuaries by going in on the ground.

The Indirect Approach does not contribute towards the U.S.'s desired end state and objectives. The Iraqi regime may be able to withstand the siege over time, in which case a stalemate will occur. Without using forces on the ground and human intelligence inside the city, U.S. forces may not be able to find and eliminate WMD early enough in the operation to prevent their use. The extraordinary physical and psychological effects of the siege are not compatible to U.S. goals of liberating the Iraqi people and installing a regime that does not pose a threat to the U.S. Instead, a harsh siege will brew hatred among the Iraqi people and among the rest of the Arab world.

In his paper on the Indirect Approach, Scales suggested that the concept might not work in every situation. He states that the nature of the population and the city are some of the key considerations that planners should examine. After reviewing those considerations, it is clear that the Indirect Approach is not feasible in Baghdad. The U.S. must take a direct approach to reach the U.S. end state and military objectives.

The U.S. should consider the following items when engaging in urban operations that have similar conditions as those that stood between the U.S. and Iraq in mid-March 2003:

1. Isolate the city, as Scales suggests.

2. Utilize ground forces and allow them to engage in combat in the city. Ground forces, in conjunction with the other components of the joint force, should focus on Iraq's critical vulnerabilities: The ability of Hussein and his inner circle to avoid death or capture; the control 
that Hussein and his inner circle have over Iraq's security forces; and the ability of Iraq's government and security forces to support and control the population. Attack key leadership targets and decisive points, without clearing the entire city in a block-to-block manner.

3. Make extensive use of human intelligence found within the city to find and destroy correct targets, to include weapons of mass destruction.

4. Strive to preserve as much of the city's infrastructure and public services as possible. This will minimize the suffering of noncombatants. It will make rebuilding the city faster and less expensive. It will also avoid alienating the population, and help to keep people in the city.

5. Encourage the population to remain in the city. This will reduce the amount of refugees that will result from the conflict.

These actions will assist in attaining the U.S.'s desired end state and objectives. The concept is to minimize the time it takes to put a new government in charge of Baghdad. It is also important to use a method that will not work against the U.S. end state and objectives. These recommendations do not provide a complete course of action for taking Baghdad. However, they are key considerations for input into any feasible course of action. 


\section{BIBLIOGRAPHY}

Arkin, William M. "Baghdad, The Urban Sanctuary of Desert Storm?" Aerospace Power Journal (Spring 1997): 8-10.

Bergquist, Robert E. The Role of Airpower in the Iran-Iraq War. Maxwell Air Force Base, AL: Air University Press, 1988.

Biddle, Stephen. Afghanistan and the Future of Warfare: Implications for Army and Defense Policy. Carlisle, PA: Strategic Studies Institute, 2002.

Bush, George W. Press Conference, 6 March 2003, available at http://www.whitehouse.gov/news/releases/2003/03/print/20030306-8.html; Internet, accessed 7 March 2003.

Cohen, Eliot A. et al. Gulf War Airpower Survey, Volume I, Planning and Command and Control. Washington, D.C., 1993.

Gulf War Airpower Survey, Volume II, Operations and Effects and Effectiveness. Washington, D.C., 1993.

Gulf War Airpower Survey, Volume V, A Statistical Compilation and Chronology. Washington, D.C., 1993.

Cordesman, Anthony H. If We Fight Iraq: The Lessons of the Fighting in Afghanistan. Washington, D.C.: CSIS, 2001.

Anthony H. Iran \& Iraq, the Threat from the Northern Gulf. Boulder, CO: Westview Press, 1994.

Iraq's Military Capabilities in 2002: A Dynamic Net Assessment. Washington, D.C.: CSIS Press, 2002.

Countrywatch. Iraq. Available at http://www.countrywatch.com, Internet, accessed 2 December 2003.

Desch, Michael C., ed. Soldeirs in Cities: Military Operations on Urban Terrain. Carlisle, PA: Strategic Studies Institute, 2001.

Freedberg, Sydney J. Jr. "Military Planners ponder the unknowns in Iraq,"National Journal (25 October 2002): 9.

Glenn, Russell W. Heavy Matter, Urban Operations' Density of Challenges. Santa Monica, CA: RAND, 2000. “...We Band of Brothers” The Call for Joint Urban Operations Doctrine. Santa Monica, CA: RAND, 1999. ed. Capital Preservation, Preparing for Urban Operations in the Twenty-First Century. Santa Monica, CA: RAND, 2001. ed. The City's Many Faces, Proceedings of the RAND Arroyo-MCWL-J8 UWG Urban Operations Conference. Santa Monica, CA: RAND, 2000.

Glenn, Russell W. et al. Denying the Widow-maker, Summary of Proceedings, RAND-DBBL Conference on Military Operations on Urbanized Terrain. Santa Monica, CA: RAND, 1998.

Hackworth, David. Interview by Fox \& Friends, 7:15 AM, 27 August 2002, Fox News Channel. 
Iraqi Army: Organization and Tactics, National Training Center Handbook 100-91. Fort Irwin, CA: National Training Center, 1991.

Janes, Iraq. Available from http://www4.janes.com; Internet; accessed 2 December 2002.

Joint Chiefs of Staff. Handbook for Joint Urban Operations. Washington, D.C.: Joint Chiefs of Staff, 2000.

Joint Chiefs of Staff. Joint Publication 3-0, Doctrine for Joint Operations. Washington, D.C.: Joint Chiefs of Staff, 2001.

Joint Chiefs of Staff. Joint Publication 3-06, Doctrine for Joint Urban Operations. Washington, D.C.: Joint Chiefs of Staff, 2002.

Medby, Jamison Jo and Russell W. Glenn. Street Smart, Intelligence Preparation of the Battlefield for Urban Operations. Santa Monica, CA: RAND, 2002.

Pape, Robert A. Bombing to Win, Airpower and Coercion in War. Ithaca, NY: Cornell University Press, 1996.

Periscope. Nations/Alliances/Geographic Regions Middle East/North Africa - Iraq. Internet, available at http://www.periscope.ucg.org/nations/mideast/iraq/navy/index.html.

Ripley, Tim. "Strategies for Iraqi Regime Change." Janes Intelligence Review (September 2002): 32.

Scales, Robert H. Jr., "The Indirect Approach: How U.S. Military Forces Can Avoid the Pitfalls of Future Urban Warfare.” Armed Forces Journal International (October 1998): 68-74. Future Warfare. Carlisle Barracks, Pennsylvania: U.S. Army War College, 1999. "Transcript of a Brief on the Army After Next," U.S. Army News Release, Washington, D.C.: Army Public Affairs, July 10, 1997, Release 97a-77.

Smith, Robert Ross. Triumph in the Philippines. Washington, D.C.: Department of the Army, 1963.

Spiller, Roger J. Sharp Corners: Urban Operations At Century's End. Fort Leavenworth, KS: U.S. Army Command and General Staff College Press, 2001.

STRATFOR, Iraq War Plans Five-Part Series. Available from http://www.dremfa.gov.ir/eng/tahlil/tahlil12_10.html ; Internet; accessed 27 October 2002.

Sumner, Mark. "The Case for Joint MOUT Doctrine;" available from http://www.urbanoperations.com/jointdoctrine.htm; Internet; accessed 15 January 2003.

Thomas, Timothy L. "The Battle of Grozny: Deadly Classroom for Urban Combat." Parameters (Summer 1999) 87-102.

Thompson, Mark. "Going Door To Door: Saddam Hussein hopes to engage Americans in street fighting in Baghdad, a scenario the U.S. wants to avoid." Time (16 September 2002): 39-41.

Turabian, Kate L. A Manual for Writers of Term Papers, Theses, and Dissertations. 6th ed. Chicago: University of Chicago Press, 1996.

United Nations, "ECPS ‘Portrait of Iraq (Draft)," 7 January 2003, available from http://www.casi.org.uk/info/undocs/ecps030107.pdf; Internet; accessed 14 February 2003.

United Nations, "Joint Government of IRAQ- UNICEF Programme Review 1990-2000," 6; available from http://www.unicef.org/iraq/library/join-1/reports.htm; Internet; accessed 2 December 2003. 
United Nations, "Likely Humanitarian Scenarios," 10 December 2002, 12; available at http://www.casi.org.uk/info/undocs/war021210scanned.pdf; Internet, accessed 14 February 2003.

United Nations, Office for the Coordination of Humanitarian Affairs. "Integrated Humanitarian Contingency Plan for Iraq and neighboring Countries," Working Draft, 7 January 2003, 911; available from http://www.casi.org.uk/info/undocs/ocha030107.pdf; Internet; accessed 14 February 2003.

United Nations, "Portrait of the Current Socio-Economic Developmental Sit uation and Implications in Iraq based on Specified Scenarios," 20 January 2003; available from http://www.casi.org.uk/info/undocs/un030120.pdf; Internet; accessed 14 February 2003.

University of Texas Library Online, Iraq Map Collection, Available from http://www.lib.utexas.edu/maps/iraq.html; Internet; accessed 5 September 2002.

U.S. Department of the Army. FM 3-06.11, Combined Arms Operations in Urban Terrain. Washington, D.C: HQs, Department of the Army, 28 February 2002.

U.S. Department of the Army. FM 3-06 (FM 90-10), Urban Operations (DRAG). Washington, D.C.: HQs, Department of the Army, 20 May 2002.

U.S. Department of the Army. FM 3-06.1, AVIATION URBAN OPERATIONS, Multiservice Procedures for Aviation Urban Operations. Fort Monroe, Virginia: US Army Training and Doctrine Command, 15 April 2001.

Vick, Alan and others. Aerospace Operations in Urban Environments, Exploring New Concepts. Santa Monica, CA: RAND, 2000.

Washington Post, Satellite Imagery of Baghdad, Available from $\mathrm{http} / / / \mathrm{www}$. washin gtonpost.com/wp-srv/inatl/longterm/iraq/maps/baghdad/front.htm; Internet; accessed 5 September 2002.

Wass de Czege and Richard Hart Sinnreich. Conceptual Foundations of a Transformed U.S. Army. The Land Warfare Papers 40 (March 2002) 16. 